\title{
Residents' Responses towards Green Initiatives by the State in Melaka Tengah District
}

\author{
Jamalunlaili Abdullah, Intan Zahida Ahmad Mustaza, \\ Che Bon Ahmad \\ Faculty of Architecture Planning and Surveying, \\ Universiti Teknologi MARA, 40450 Shah Alam, Selangor, Malaysia \\ jamal858@salam.uitm.edu.my, chebon848@salam.uitm.edu.my
}

\begin{abstract}
Initiatives of sustainable development require acceptance and participation of the people. This is crucial for Melaka state which wants to be a Green Technology City State by 2020. This paper evaluates the people's acceptance and participation of these programs. Observations, responses from 152 samples, and in depth interview of officers were analysed. The study suggests the respondents are aware of the green city's vision, mostly from social media. The popular initiatives are Melaka Without Plastic Bag and Polystyrene, Green Transportation and 2+1 Recycling Program. However, the level of people's involvement in the initiative introduced is relatively low.
\end{abstract}

Keywords: Green Technology Sustanable City (GTSC); sustainable development; public responses; Melaka

eISSN 2398-4279 @ 2019. The Authors. Published for AMER ABRA cE-Bs by e-International Publishing House, Ltd., UK. This is an open access article under the CC BY-NC-ND license (http://creativecommons.org/licenses/bync-nd/4.0/). Peer-review under responsibility of AMER (Association of Malaysian Environment-Behaviour Researchers), ABRA (Association of Behavioural Researchers on Asians) and CE-Bs (Centre for EnvironmentBehaviour Studies), Faculty of Architecture, Planning \& Surveying, Universiti Teknologi MARA, Malaysia.

DOI: https://doi.org/10.21834/ajqol.v4i16.194 


\subsection{Introduction}

Melaka, one of the fourteen states in the Federation of Malaysia, aspires to be a developed state by 2020. In addition to economic growth, Melaka aims to protect its natural resources and to limit the harm to its environment due to rapid economic growth. In addition to its protection of natural environment, Melaka strives to be a green city state through its adoption of Melaka Green Technology Sustainable City (GTSC) blueprint.

There are various green initiatives especially related to green technologies which are contained within the GTSC blueprint to be implemented within the state. These include energy efficiency and renewable energy, water management, green transportation, zero waste, urban agriculture and forestry and cultural heritage and tourism. They are to be implemented in stages from 2012 until 2023.

Public acceptance and participation are important components of the success of any government initiatives. Melaka GTSC is of no exception. This is especially true since these initiatives require the participation of the people. High rate of participation requires acceptance in the first place. Awareness and knowledge of the public regarding the green initiatives are key factors in the success of this vision. Lack of awareness and knowledge causes people not to be concerned about the importance of preserving and conserving the environment. However, a high level of awareness will shape the behaviour of a person thus helping the government. Normally public awareness starts with their background. Generally, individuals with a good education background have a higher awareness than those with lower level of education. In addition to educational level, the attitude and knowledge of individuals of these green initiatives are also important factors that influence the success of GTSC. The involvement of the public can be an important opportunity to improve the quality and effectiveness of such decisions. This is because the success of a government initiatives depends not only on state administrations, but also the support and participation of the public. This research covers three main components which are theory of sustainable development in relation to Melaka Green Technology City State (GTCS) 2020, to evaluate the public understanding, acceptance and participation in GTCS programs, and to recommend ways to improve public acceptance and participation in the said programs.

\subsection{Literature Review}

Sustainable Development is very much part of urban policies and strategies worldwide. The famous Brundtland's definition of sustainable development states that it is 'development that meets the need of the present without promising the ability of future generations to meet their own needs' (WCED, 1987, p. 43). This was followed by the 27 principles adopted during the Rio Conference of 1992. The principles emphasized that sustainable development is concerned about both intra-and intergenerational value. From the principles, it additionally takes after that sustainable development is a coordinating idea specifically that environment is a fundamental piece of the development process, and also highlight the linkages of sustainable development to peace and security (Meakin, 1992).

Agenda 21 is a blueprint for achieving sustainable development that was adopted at the UNCED as well. It covers actions at all levels which are local, national, regional and 
international. Its forty chapters are placed in four sections which is (1) Social and Economic Dimensions, (2) Conservation and Management of Resources for Development, (3) Strengthening the Role of Major Groups and (4) Means of Implementation. (Stakeholder Forum for a Sustainable Future, 2012). In September 2015 Heads of State and Government consented to set the world on the way towards sustainable development through the adoption of the 2030 Agenda for Sustainable Development. This agenda includes 17 Sustainable Development Goals (SDGs). This set out quantitative objectives over the social, economic, and environmental dimensions of sustainable development to be accomplished by 2030 The SDGs expand upon the accomplishment of the 8 Millennium Development Goals (MDGs) settled upon in 2000 to halve extreme poverty by 2015 as a midpoint towards eradicating poverty in the entirety of its stages (Schutt, 2015).

Malaysia has strived to implement the SDG in the nation. It has formulated the National SDG Roadmap to guide implementation of the 2030 Agenda and the SDG. In addition, Malaysia also has implemented the New Urban Agenda to ensure that sustainable development is carried out in urban areas (Economic Planning Unit, 2017). The New Urban Agenda was accepted at the Habitat 3 conference in Quito in October 2016. It is an activity arranged record which will set worldwide guidelines of accomplishment in the pursuit of sustainable urban development, rebuild the way people think, manage and live in cities through collaboration with committed partners and relevant stakeholder engagement at all levels of the government as well as the private sector (Stephens, 2018). Melaka has initiated a clear path toward more sustainable urban growth. Government efforts include the implementation of policies and projects, as well as private sector and citizen initiatives that strengthen the economy and improve liveability in Melaka. Melaka took the first step by focusing on more comprehensive approaches and is especially concerned with long-term plan towards urban sustainability when it implemented the Green Technology Blueprint in 2011 and formalized a vision to transform Melaka into a Green Technology City State by 2020 (MBMB 2017).

The Blueprint Melaka Maju Negeriku Sayang, Negeri Bandar Teknologi Hijau, 2011-2020 was launched in November 2011. Aligned with the declaration of Melaka as Developed State on 20th October 2010, the Blueprint act as a comprehensive document which provides direction and guidance to Melaka in becoming a sustainable city state. The blueprint targets the people to take active role in spearheading the sustainability transformation. In addition, Melaka has established the Perbadanan Teknologi Hijau Melaka (PTHM) in order to achieve its vision and adopt the United Nations Urban Environmental Accords (UEA) rating method for assessing Melaka's green city performance. Melaka has signed the United Nations Urban Environmental Accords (UEA) which provides a series of feasible implementations that can be adopted at the city level to achieve urban sustainability, promote healthy economies, promote social equity and protect the world's ecosystems. The UAE recommends implementing action plans across seven thematic areas which are energy, waste, urban design, urban nature, transportation, environmental health and water.

Apart from that, Melaka also adopted Melaka Green City Action Plan (GCAP) in 2014. The GCAP is an overarching document for sustainable urban development in Melaka and the Blueprint becomes a subset document. The Blueprint is a short-term strategy with the 
main purpose of achieving the status of Green Technology City State by 2020. The GCAP provides a set of recommendations that are aimed at maintaining Melaka's competitiveness as a popular tourist and investment destination, keeping environmental challenges to a minimum, and establishing the state as a role model for liveability in the region. Melaka has initiated numerous green initiatives (MBMB 2017). Among the successful efforts is the transformation of the Melaka River from a polluted backyard drainage canal into a vibrant and liveable water front with high economic value. The initial transformation has required an integrated effort and nearly a decade to construct wastewater infrastructure, adopt historic preservation and place making measures and pursue economic development strategies to create an urban waterfront with a river walk and river cruise experience that has become a popular tourist attraction (Krishnan 2014).

Public Acceptance and Participation is crucial for the success of the initiatives proposed in Melaka State. Sherry Arnstein's works of 1969 ranked the typology of citizen participation which includes eight rungs which are manipulation, therapy, informing, consultation, placation, partnership, delegated power and citizen control. It shows the progression towards increased levels of decision making powers. Arstein's limitation to her work is also acknowledged by Conor (1988) who has stated that while her work consists of 8 rungs, real world application may require as many as 150 to cover the range of actual citizen involvement levels'. As a result of this limitation, Connor (1998) has developed another ladder model to complement Arnstein's ladder. The success of the programs on Melaka depends on which rung of public participation the people are involved with.

\subsection{Methodology}

This research uses both, quantitative and qualitative approach. The first includes observations of behaviours at events related to the green initiatives' programs. Interviews were conducted with officers from Majlis Bandaraya Melaka Bersejarah and Melaka Green Technology Corporation Officer.

Quantitative analysis is based on a questionnaire survey of 152 people identified as locals who work and live in Melaka Tengah.

Table 1 below is the summary of respondents' profile which shows two third were women, slightly over 10 percent were non-Malaysians while the age distribution was rather even among all age groups. In terms of education, almost half of respondents had tertiary education of certificate and above. Professionals constitute the largest percentage of respondents although almost all major occupations are represented. This showed that respondents who participated in the survey represent the vast spectrum of the population.

Table 1. Summary of Respondents' Profile

\begin{tabular}{llll}
\hline $\begin{array}{l}\text { Background } \\
\text { of } \\
\text { Respondent }\end{array}$ & Category & Frequency & Percent (\%) \\
\hline \multirow{2}{*}{ Gender } & Male & 50 & \\
\cline { 2 - 4 } & Female & 102 & 32.9 \\
\hline & Malaysian & 135 & 67.1 \\
\hline
\end{tabular}


Abdullah, J., et.al. / Asian Journal of Quality of Life (AjQoL), 4(16) May/Aug 2019 (pp.33-46)

\begin{tabular}{|c|c|c|c|}
\hline Nationality & Non-Malaysian & 17 & 11.2 \\
\hline \multirow{5}{*}{ Age } & Under 18 years & 16 & 10.5 \\
\hline & $18-24$ years & 31 & 20.4 \\
\hline & $25-54$ years & 37 & 24.3 \\
\hline & $55-65$ years & 34 & 22.4 \\
\hline & 65 Years and Above & 34 & 22.4 \\
\hline \multirow{5}{*}{$\begin{array}{l}\text { Educational } \\
\text { Status }\end{array}$} & Primary School & 1 & 0.7 \\
\hline & Lower Secondary & 7 & 4.6 \\
\hline & Upper Secondary & 71 & 46.7 \\
\hline & Tertiary (Certificate or Diploma) & 48 & 31.6 \\
\hline & Tertiary (Degree/Advanced Diploma and Above) & 25 & 16.4 \\
\hline \multirow{11}{*}{ Occupation } & Managers & 3 & 2.0 \\
\hline & Professionals & 37 & 24.3 \\
\hline & Technician and Associate Professionals & 10 & 6.6 \\
\hline & Clerical Support Workers & 6 & 3.9 \\
\hline & Service and Sales Workers & 16 & 10.5 \\
\hline & $\begin{array}{l}\text { Skilled Agricultural, Forestry, Livestock and Fishery } \\
\text { Workers }\end{array}$ & 7 & 4.6 \\
\hline & Craft and Related Trades Workers & 1 & .7 \\
\hline & Plant and Machine Operators and Assemblers & 25 & 16.4 \\
\hline & Unemployed & 7 & 4.6 \\
\hline & Retiree & 25 & 16.4 \\
\hline & Student & 15 & 9.9 \\
\hline
\end{tabular}

\subsection{Results and Discussion}

This section presents the findings for respondents' knowledge, the respondents 'acceptance and the respondents' participation in the State of Melaka Green Technology City State.

\subsection{Respondents' Knowledge}

\subsubsection{Green Initiative Awareness}

Table 2. Respondent's Green Initiative Awareness

\begin{tabular}{lll}
\hline Green Initiative Awareness & Frequency & Percent (\%) \\
\hline Yes & 149 & 98.0 \\
\hline No & 3 & 2.0 \\
\hline Total & 152 & 100.0 \\
\hline
\end{tabular}

Table 2 above indicates the 2 percent of respondents who have never heard of green technology event are non- Malaysian even though it has been implemented for eight years. It might be because of unsuccessful of information delivery or they have just settled in Melaka. 


\subsubsection{Information Resources on Green Initiatives}

Table 3 below shows 26.3 percent of respondents said they obtained the information online, followed by 24.3 percent obtained information from newspaper and 15.8 percent obtained information from their workplace. Cross tabulation shows that both social media and traditional media are still relevant in a way to spread information. This is because both the younger generation and older generation use both methods to keep up to date on what's going on around them.

Table 3: Respondent's Source of Information and Age Cross Tabulation

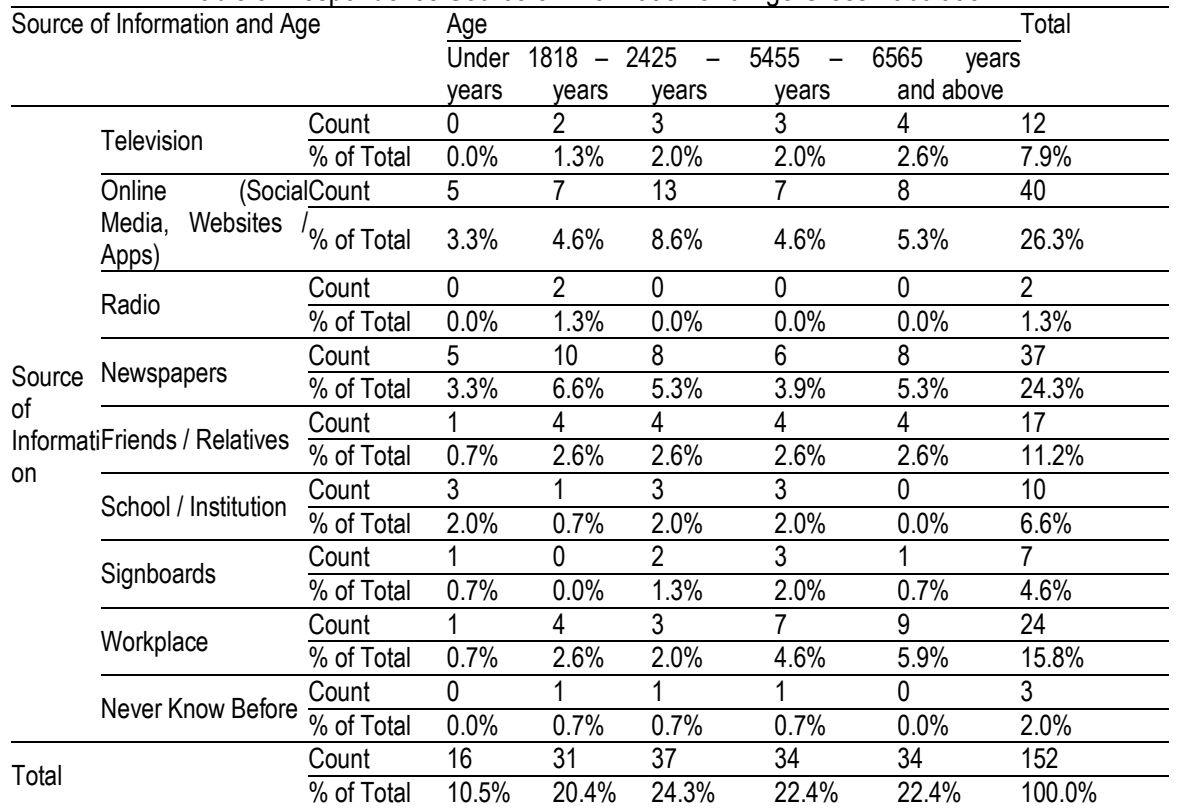

\subsubsection{Respondents' Knowledge of Green Initiatives}

Figure 1 below shows 27.6 percent of respondents are aware of the Melaka Without Plastic Bag Programs, followed by 22.4 percent know about Green Transportation Program and 14.5 percent aware of the $2+1$ Recycling Program. These programs are easily assessable by respondents in their day-to-day lives. For example, respondents have a great chance to use the vehicle (Green Transportation) on a daily basis compared to gardening. This shows that programs that are not directly involved in respondents' daily activities have low percentages compared to the program where the respondents are directly involved daily. 


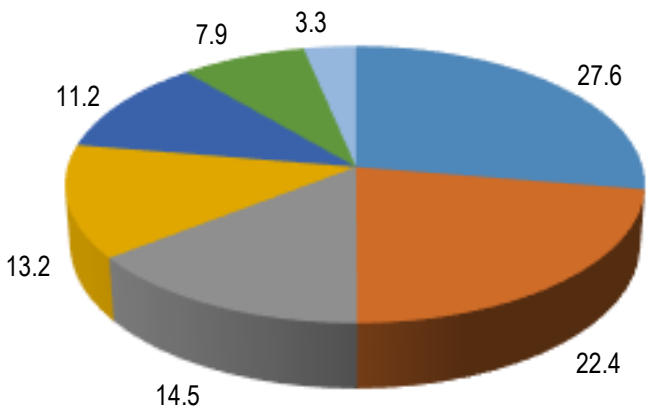

Melaka Without Plastic Bag and Polystrene

Green Transportation

2+1 Recycling Program

E-Waste Alam Alliannce

- Urban Farming

- Vermicompost

Melaka Biodiesel Program

Figure 1. Respondent's Knowledge on Green Initiatives

\subsection{Respondent's Acceptance of Melaka Green Technology City State}

\subsubsection{Respondent's Acceptance of GTCS}

Table 4 below shows that 91.4 percent of respondents are accepting government vision to transform Melaka into a Green Technology City State and only 8.6 percent of respondents rejected the vision. It is further reveals that respondents working in the professional field are the largest group accepting the aspiration with 25 percent of respondents, follow by 19.1 percent are from retired groups and 14.5 percent come from people who work in plant and machine operators and assemblers' groups. This data indicates that this vision is accepted regardless of the background of the respondent's occupation.

\subsubsection{Reasons for Accepting GTCS}

Table 5 below, 38.2 percent of respondents accepting government vision to transform Melaka into a Green Technology City State for the next generation sustainability, follow by 27 percent respondents think that that the government is ready to implement green technology initiatives, 17.8 percent respondents want to help our environment to continue on and to maintain it as it is, and 8.3 percent respondents choose to help reduce costs as well as benefit the overall economic.

Table 5: Respondent's Reason for Accepting Melaka Green Technology City State Respondent's Reason for Acceptance

\begin{tabular}{lll}
\hline The government is ready to implement green technology initiatives & 41 & 27 \\
\hline For the next generation sustainability & 58 & 38.2 \\
\hline Help our environment to continue on and to maintain it as it is. & 27 & 17.8 \\
\hline Help to reduce costs as well as benefit the overall economic & 13 & 8.3 \\
\hline
\end{tabular}


Awareness is a prelude to informed action. In democratic societies like Malaysia, actions towards sustainable development ultimately depend on public awareness, understanding and support. Common information and shared understanding are important not only for mobilizing public support but also for carrying out work consultative and participatory approaches in all fields. The findings suggest that most Melaka societies are well aware of the factors on a complex issue such as sustainable development. Thus, this growing public environmental awareness provides an opportunity to help advance civic development in Melaka.

\subsubsection{Reasons for Not Accepting GTCS}

For the reasons of not accepting the aspiration, Table 6 below shows 4 percent of respondents rejected the idea because they think the implementation of green technology involves risks and uncertainties, 2 percent choose higher costs of environmental compliance, another 2 percent said that government is not ready to implement the green technology initiative and 0.7 percent argues that Melaka does not require any new changes However, the number of people who rejected the idea was so small compared to those who accepted.

Table 6: Respondents Reason for Not Accepting to Transform Melaka into a Green Technology City State

\begin{tabular}{lll}
\hline Respondents Reason for Not Accepting & Frequency & Percent (\%) \\
\hline Higher costs of environmental compliance. & 3 & 2 \\
\hline The government is not ready to implement green technology initiative. & 3 & 2 \\
\hline $\begin{array}{l}\text { The implementation of green technology involves risks and } \\
\text { uncertainties. }\end{array}$ & 6 & 4 \\
\hline Melaka does not require any new changes. & 1 & 0.7 \\
\hline Total & 13 & 8.7 \\
\hline
\end{tabular}

\subsection{Respondent's Participation of Melaka Green Technology City State}

\subsubsection{Respondent's Participation of GTCS}

Table 7 below shows that 81.6 percent respondents participated in the green initiatives, whereas 18.4 percent said they were not interested in responding to government's vision.

Table 7: Respondent's Participation

\begin{tabular}{lll}
\hline Participation & Frequency & Percent (\%) \\
\hline Yes & 124 & 81.6 \\
\hline No & 28 & 18.4 \\
\hline Total & 152 & 100.0 \\
\hline
\end{tabular}




\subsubsection{Reasons for Participating GTCS}

Table 8 below indicates, half of the respondents who participated in the initiative said that they did it because they felt like it's their responsibility, in comparing only 17.1 percent respondent said they want to help our environment to continue on and to maintain it as it is and 14.5 percent are doing it for the next generations. This shows that people in Melaka are not self-oriented when it comes to addressing environmental problems and they are well informed of the need for sustainable development.

Table 8: Respondents Reason in Accepting to Transform Melaka into Green Technology City

State

\begin{tabular}{lll}
\hline & Frequency & Percent (\%) \\
\hline I feel like it's my responsibility & 76 & 50 \\
\hline I do it for the next generations & 22 & 14.5 \\
\hline I want to help our environment to continue on and to maintain it as it is. & 26 & 17.1 \\
\hline Total & 124 & 81.6 \\
\hline
\end{tabular}

\subsubsection{Reasons for Not Participating GTCS}

However, the number of people taking part in the Melaka Green Technology City initiative is lower than the number of people who accept it. This suggests that not all respondents who accept this vision will adopt the initiatives undertaken. There are several reasons that can explain this situation (Figure 2 below).

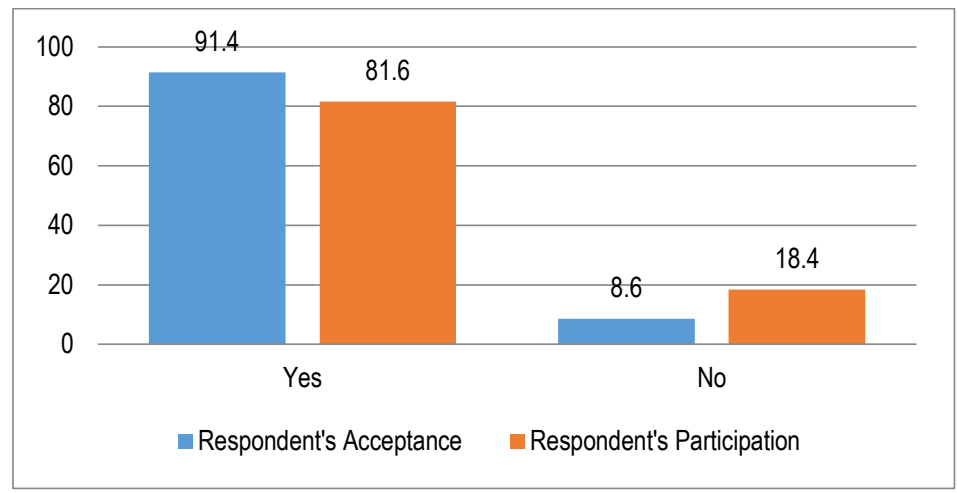

Figure 2: Respondent's Acceptance Occupation by Percentage

The data (Table 9) below shows that respondents who are not involved in green initiatives are because they lack proper knowledge about the importance of green practice. Thus, prove that education serves society by providing a critical reflection on the world by promoting greater consciousness and awareness. Education is also a way to disseminate knowledge and develop skills to bring about the desired change in behavior, values and lifestyles in which can help promote public support for the continuing and fundamental changes. 
Table 9: Respondents Reason in Not Accepting to Transform Melaka into Green Technology City State

\begin{tabular}{lll}
\hline & Frequency & Percent (\%) \\
\hline It requires too much effort. & 3 & 2 \\
\hline I don't have a like-minded community interested in going green. & 10 & 6.6 \\
\hline It's too expensive. & 5 & 3.3 \\
\hline I feel like I am doing it all alone. & 5 & 3.3 \\
\hline I don't know where to begin. & 4 & 2.6 \\
\hline Total & 27 & 17.8 \\
\hline
\end{tabular}

\subsubsection{Respondent's Participation by Green Initiatives Implemented}

Five pre-coded responses type of question is used to allow the individual to express how much they 'agree' or 'disagree' with a particular statement based on green initiatives that have been implemented in Melaka as below:

- Melaka Without Plastic Bag and Polystyrene

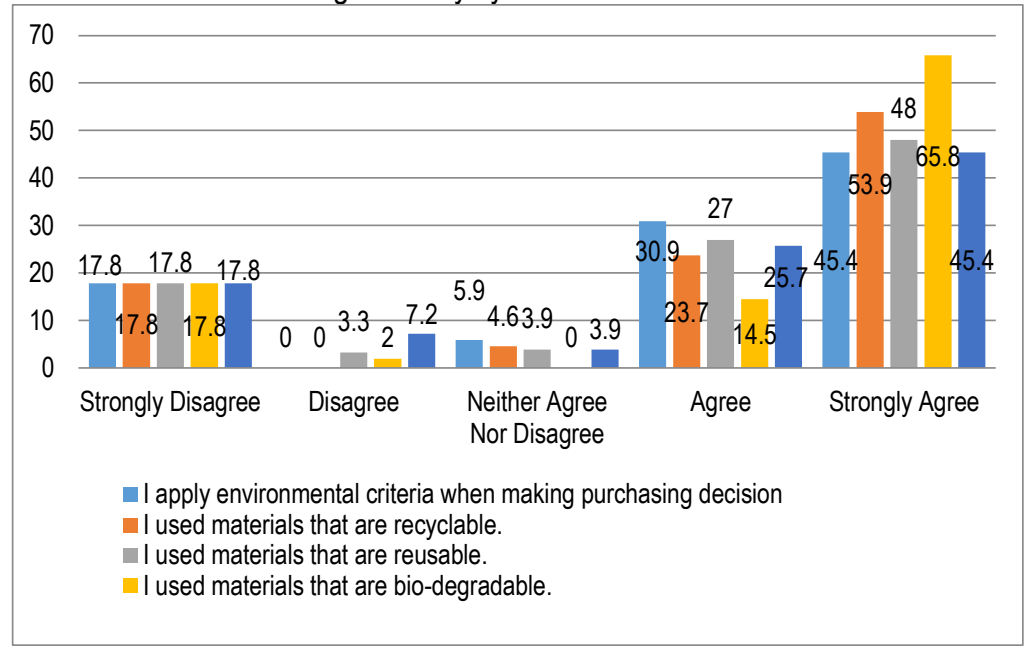

Figure 4: Responses to Melaka Without Plastic Bag and Polystyrene Program

Figure 4 shows there are a few criteria in order to identify the level of consumer participation in the program. From the figure below, 65.8 percent said that they 'strongly agree' in using material made of bio degradable. This is because Melaka only allows the use of biodegradable plastic bags. Business owner are required to replace plastic bags with biodegradable plastic bag. At the same time, hawkers and eateries are not being allowed to use polystyrene packaging. This led to the huge production of bio-degradable plastic bag in Melaka and it is easily found in large hypermarkets up to hawker shop. Apart from that, 53.9 percent of respondents said that they used materials that are recyclable and 48 percent respondents said that they used materials that are reusable. This is because the culture of 
carrying reusable plastic bags has slowly become the practice of Melaka citizen. Most people who want to buy goods in supermarkets or any shops will bring along their reusable bags to show their support for the government's effort. The total mean score for Melaka Without Plastic Bag and Polystyrene program is 3.9 which indicated that most of the respondents participate in the program. This is because, the ban on use of plastic bags has been introduced since 2014 and this implementation is in stages. The duration of the 4 years of implementation has been success familiarize the people to not use plastic bags. Another factor contributing to this successful is because of the strict enforcement with the maximum fine of RM250 would be imposed on traders who failed to comply with the enforcement notice issued by the relevant authorities.

- Melaka Biodiesel Program

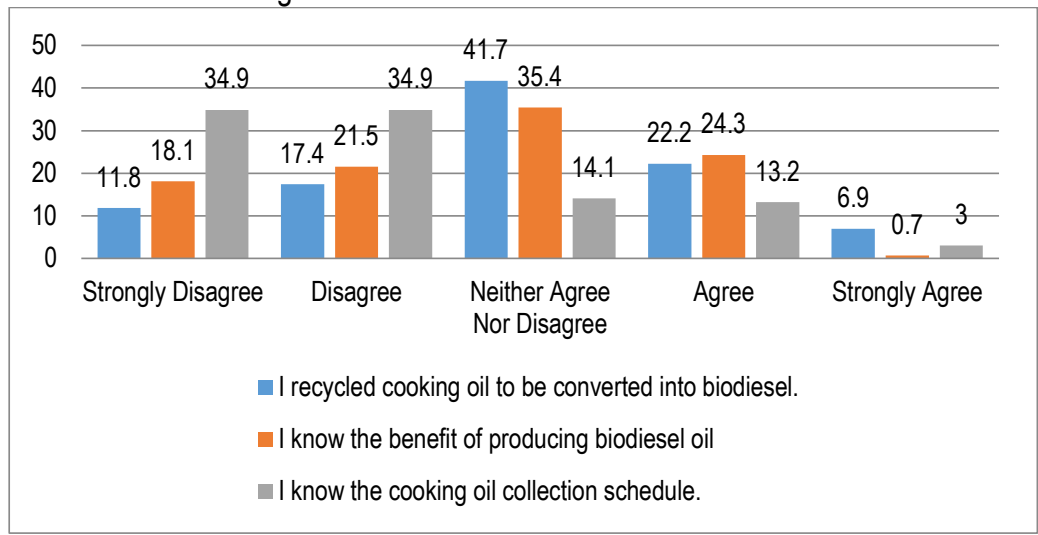

Figure 5: Responses to Melaka Biodiesel Program

Figure 5 shows that most respondent choose to be in 'neither agree nor disagree'.

This indicated that some respondent's might be neutral because they have some positive and negative thoughts, but others might be neutral because they don't know about the program. Although the program has started since 2011, the program has not received a great welcome from the locals. This is because the program is not widely disclosed and loosely enforced as compared to successful programs such as Melaka Without Plastic Bag and Polystyrene. The use of bio-diesel in vehicles, electric generators and machines in Melaka is not very widespread causing few people not aware of the existence of this program. Apart from that, the program is optional and only relies on the awareness of the people themselves which means the people have option to either recycle or not. 
- $2+1$ Recycling Program

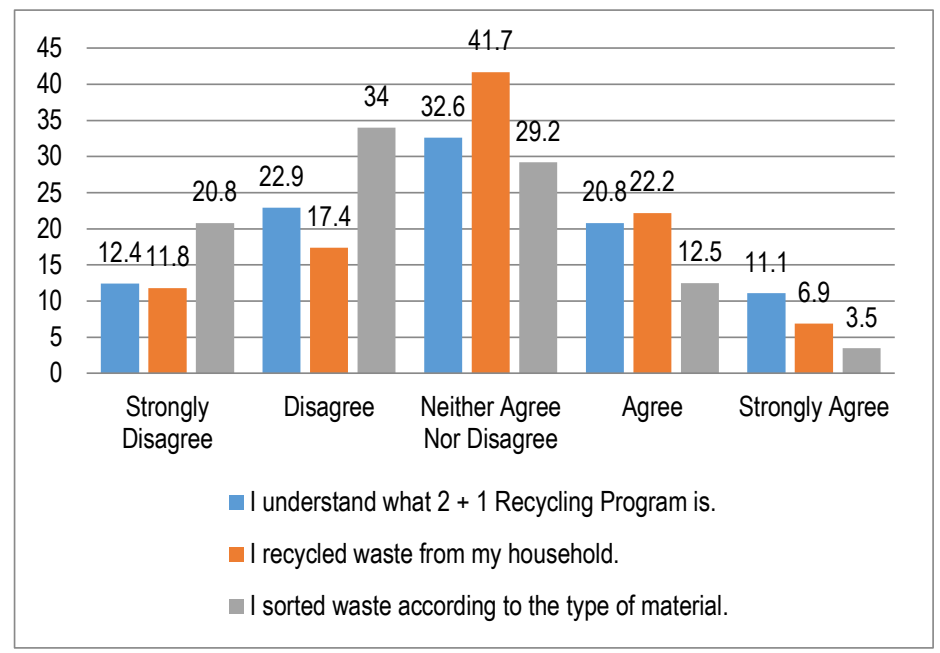

Figure 6. Responses to 2+1 Recycling Program

Figure 6 shows the majority of respondents choose 'neither agree nor disagree' for each given criteria. This program is seen to be getting less participates from the local people. This is because the program is optional, where they can either join or not. Thus, this program depends on public awareness itself. It can be said that the main factor in the lack of involvement of the public is due to lack of awareness and knowledge of recycling practices.

- Green Transportation

Referring to Table 7 below, it shows that respondents used green vehicles in their lives, but they have not yet use green vehicles as their daily main mode of transport. Only bicycles and electric buses are easily available in Melaka. This is due to the low number of electric vehicles in Melaka as the expensive prices have become the main cause of owning the electric car. On average, most respondents say that the use of electric vehicles has been widespread in Melaka. While the state government has taken the initiative to provide electric charging stations, there are many other factors that have become a barrier to the success of the program. According to Mrs. Nurliana Binti Zainul Adnan, Melaka Green Technology Corporation Officer, among the factors are the electric vehicle is costly than gasoline powered cars within the same range. Maintenance costs as a result of new technology and developing skills between mechanics makes electric vehicles even more of a costly proposition. The second factor is electric vehicles are limited mileage range. A complete battery recharge takes up to eight hours and there are limited quick charge plug-in stations available across the country. Thus, not many local people are able to buy electric cars. Based on researchers' observations, the use of bicycles in Melaka is particularly encouraging, especially in urban areas. The government's initiative in providing bicycle rental systems encourages the use of 
bicycles. The use of electric vehicles is only practiced at the government level used by enforcement officers on duty. However, the use of bicycles to work has yet to be practised because of Malaysia's unsuitable weather for cycling especially in the afternoon

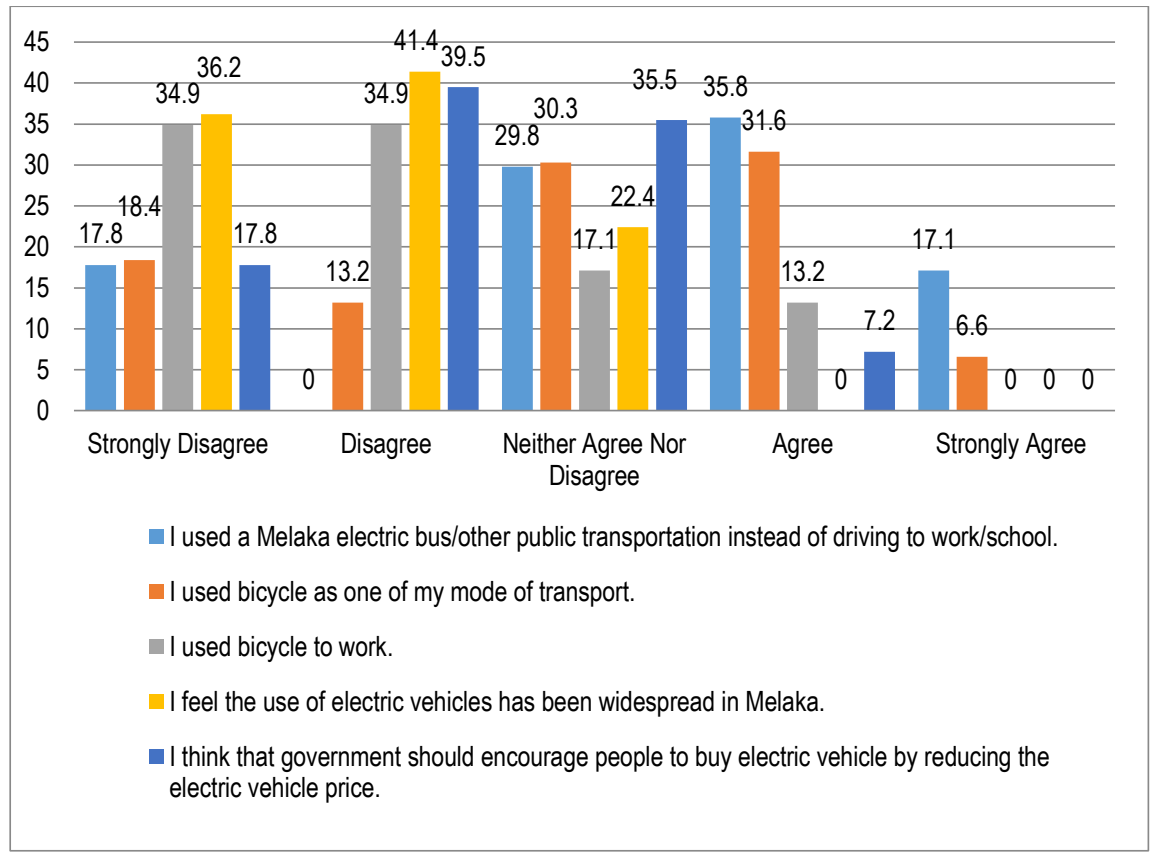

Figure 7: Percentage of Agreement Scale for Green Transportation Program

\subsection{Conclusion}

Melaka has successfully applied green initiatives approach through the Blueprint Melaka Maju Negeriku Sayang, Negeri Bandar Teknologi Hijau and Melaka Green Action Plan to develop high-impact, low-cost strategies that can be speedily performed. Many initiatives have been successfully implemented to tackle a broad range of social, economic and environmental issues. As a result, the state's economic growth is balanced with excellent green efforts. Nevertheless, the involvement of the people in the initiatives introduced is still at a dismal level. This is due to the lack of awareness and knowledge of green technology in Melaka. Only a few initiatives have received good support from the people including the Melaka Without Plastic Bag and Polystyrene Program. This is due to the fact that the state government has strict enforcement of the program.

Promoting green behaviour is a complex task. It involves tapping into habitual and deliberative processes at individual, household and social levels, and working within the triangle of government, business and consumer. Policymakers will need to strike a balance between including the increasing range of scientific and theoretical insights whilst maintaining 
a practical approach that is transparent to stakeholders. In order for Melaka to continue to implement various green technologies to achieve its status as a green city state, all parties must join hands in the efforts and vision of making. Awareness and knowledge of green technology among the people as well as their active involvement are needed to achieve the goal of Melaka green initiatives.

\section{Acknowledgement}

The authors like to extend the utmost appreciation to the respondents and community of Melaka District, for providing the related information. The authors also acknowledge the constructive comments from the peer reviewer for reviewing the manuscript.

\section{References}

Bishop, K., \& Said, I., (2017). Challenges of Participatory Qualitative Research in a Malaysian and Australian Hospital. Asian Journal of Environment-Behaviour Studies, 2(4), 1-11.

Collado, S., \& Corraliza, J., A. (2017). Children's Perceived Restoration and Pro-Environmental Beliefs. Journal of ASIAN Behavioural Studies, 2(2), 1-12.

Fachinger, J., den Exter, M., Grambow, B., Holgerson, S., Landesmann, C., Titov, M., et al. (2004). Behavior of spent HTR fuel elements in aquatic phases of repository host rock formations, 2nd International Topical Meeting on High Temperature Reactor Technology. Beijing, China, paper \#B08.

Mehdi K., \& Koorosh, A. (2015). Achievement to Environmental Components of Educational Spaces for Iranian Trainable Children with Intellectual Disability. Procedia - Social and Behavioral Sciences, 201, 9-18.

Mettam, G. R., \& Adams, L. B. (1999). How to prepare an electronic version of your article. In B. S. Jones \& R. Z. Smith (Eds.), Introduction to the electronic age (pp. 281-304). New York: E-Publishing Inc. 